\title{
PACTOS Y TENSIONES EN UN ESPACIO DE PLURALIDAD IDENTITARIA Y JURISDICCIONAL. EL SUDESTE PENINSULAR A INICIOS DEL SIGLO XV
}

\author{
Juan Leonardo Soler Milla \\ José Carlos López García \\ Universidad de Alicante
}

\section{RESUMEN}

Las razzias y las agresiones entre miembros de distinta soberanía o comunidad religiosa en los espacios de frontera bajomedievales, provocaron en sus sociedades una reacción contra la misma en forma de instituciones y pactos para la persecución de los malhechores y la restitución de las víctimas. En el presente artículo se analiza la eficacia de acuerdos como la Hermandad entre cristianos y musulmanes en la Gobernación de Orihuela y la colaboración entre el Adelantamiento de Murcia y la Gobernación de Orihuela para resolver incidentes fronterizos, a partir de casos que reflejan las trabas que implicaban la multiplicidad de jurisdicciones, la connivencia con los delincuentes y la confrontación de intereses, de modo que supone una revisión de los trabajos previos referidos a este tipo de instituciones y acuerdos.

Palabras clave: Hermandad, Orihuela, Murcia, Granada, aljamas musulmanas, frontera, cautivos, almogávares.

\begin{abstract}
In early-medieval border areas, the razzias and aggressions between members of different sovereignties or religious communities triggered adverse reactions in their societies, embodied in the form of institutions and pacts to persecute wrongdoers and to compensate victims. This article discusses the effectiveness of agreements such as the Brotherhood between Christians and
\end{abstract}


Muslims in the Orihuela Governorate and the collaboration between Murcia's Adelantado Mayor (a form of Governor) and the Orihuela Governorate to solve border incidents. The analysis is based on cases that reflect the hurdles brought about by the multiple jurisdictions, collusion with criminals and conflicts of interests. A review of previous work on such institutions and agreements is thus included.

Keywords: Brotherhood, Orihuela, Murcia, Granada, Muslim aljamas, border, captives, Almogavars.

\section{INTRODUCCIÓN}

La frontera como sujeto histórico invita a seguir formulando nuevos planteamientos, así como una revisión, sobre los fenómenos sociales, económicos y políticos de los espacios territoriales articulados en los límites de las coronas de Aragón y de Castilla, más el Reino de Granada, entre los siglos XIII y XV. Los objetivos de continuar analizando los fenómenos propios de las sociedades de frontera son: entender el perfil humano de sus protagonistas, las construcciones y reacciones identitarias, las causas políticas y socioeconómicas de esos fenómenos, y, en definitiva, entender las dinámicas de interacción social e interterritorial que tenían lugar. Bazzana reflexiona, y nos hace reflexionar, sobre el concepto de "frontera" como realidad concreta donde pueden desarrollarse reacciones opuestas, como la atracción por su viveza y dinamismo, o el rechazo, dando lugar al despoblamiento, por sus peligros. ${ }^{1}$ Pero ambas reacciones pueden ser la cara de una misma moneda y coincidir, sin resultar contradictorio en un mismo espacio.

La expansión cristiana sobre los territorios meridionales islámicos supuso la creación en el sudeste peninsular de una nueva sociedad basada en los modelos sociales y estructurales propios de su lugar de origen, ${ }^{2}$ el área cristiana septentrional peninsular. El hecho de dar lugar a nueva sociedad, denominada fronteriza por la historiografía, se debe a diversos factores. En primer lugar, a las relaciones y fenómenos sociales, cuando no "patologías", inherentes a la dinámica resultante de la materialización de una fronte-

1 BAZZANA, A.: "El concepto de frontera en el Mediterráneo Occidental en la Edad Media", Actas del Congreso La Frontera Oriental Nazarí como Sujeto Histórico (S. XIIIXVI), Pedro Segura Artero (coord.), ed. Instituto de Estudios Almerienses, Almería, 1997, p. 26.

2 JIMÉNEZ ALCÁZAR, J.F: "Et por estar esta tierra en frontera de moros. Sociedad y territorio en la frontera de Granada (siglos XIV-XV)", Monasterios, espacios y sociedad en la España cristiana medieval. X Semana de Estudios Medievales. Nájera, del 3 al 7 de agosto de 2009, José Ignacio de la Iglesia Duarte (coord.), Instituto de Estudios Riojanos, Logroño, 2010, p. 387. 
ra, es decir, de la aparición traumática de realidades diferentes compuestas de factores distintos y opuestos de diversa índole (lingüísticos, religiosos, geopolíticos, antropo-geográficos y bio-geográficos). ${ }^{3} \mathrm{Y}$ en segundo lugar, por el perfil social de un elemento humano motivado a la colonización por la Corona, pero arrastrado por unos intereses personales que dibujarán la frontera como un espacio de oportunidades o de inseguridades.

Entre las oportunidades estarían la obtención de propiedades y las mayores posibilidades de promoción social; ${ }^{4}$ y en cuanto a la sensación de inseguridad, ésta estaría motivada por la permisividad para que poblaran el territorio individuos huidos de la justicia, y bandidos o malhechores seducidos por las ganancias en forma de botín que la inseguridad e inestabilidad fronteriza les podía reportar. ${ }^{5}$

La frontera simbolizará posesión militar o política y se articulará como un vivo tablero de juego donde pugnarán fuerzas o entidades regnícolas diferentes, en expansión o en retroceso, por sus intereses geopolíticos. Pero en primera instancia, en su cotidianidad, la frontera es una dimensión humana, pues va a ser la población que lo habita, caracterizada por su heterogeneidad y dinamismo, quien la va a definir y a concretar. ${ }^{6}$ El poder real va a ser consciente de ello en cuanto que es capaz de trazar una estrategia de consolidación de sus posesiones fronterizas. Por un lado, a partir de la creación de identidades ${ }^{7}$ que estarán formadas por elementos comunes y diferenciadores con respecto al otro, como la lengua, la religión, las costumbres, los lazos familiares o el lugar de nacimiento, pero soportadas por la construcción de una memoria histórica basada tanto en el proceso de expansión y conquista como en los conflictos bélicos recientes. ${ }^{8} \mathrm{Y}$ por otro lado, por la integración

3 Como indica Bazzana (art. cit., 27), la frontera como objeto histórico no existe.

4 JIMÉNEZ ALCÁZAR, J. F.: "Et por estar esta tierra...", 387-389.

Las oportunidades de ascenso social son latentes en la caballería villana, procedente de la baja nobleza o del estamento ciudadano, que integraría la oligarquía urbana de una villa de frontera como Orihuela (véase BARRIO BARRIO, J.A.: "La articulación de una oligarquía fronteriza en el mediodía valenciano. El patriciado de Orihuela. Siglos XIII-XV", Revista d'Historia Medieval, 9 (1998), pp. 105-126).

5 FERRER I MALLOL, $\mathrm{M}^{a} \mathrm{~T}$.: La frontera amb l'Islam en el segle XIV. Cristians i serraïns al Pais Valencià, ed. CSIC, Barcelona, 1988, pp. 47-48.

6 JIMÉNEZ ALCÁZAR, J. F: "Et por estar esta tierra...", 386.

7 ORTUÑO MOLINA, J.: "Definiciones identitarias y conflictividad en la Edad Media. Las relaciones de frontera entre los reinos cristianos de Murcia y Valencia en los siglos XIII-XVI", Anuarios de Estudios Medievales, 41/1 (2011), p. 74.

8 Véase BARRIO BARRIO, J. A.: "La construcción de modelos de identidad urbana en las villas y ciudades de la Gobernación de Orihuela, ss. XIII-XV", Canelobre. Revista del Instituto Alicantino de Cultura "Juan Gil-Albert", 52 (2007), pp. 240-253; CABEZUELO PLIEGO, "Guerra y violencia en un espacio frontero", Canelobre. Revista del Instituto Alicantino de Cultura "Juan Gil-Albert", 52 (2007), pp. 42-56. 
de los espacios anexionados en una entidad monárquica que ejerce como eje central del edificio institucional construido. ${ }^{9}$

La estrategia, más que sobre el territorio, se cierne sobre el elemento humano que debía erigirse como el defensor sobre el terreno del espacio rayano. Sin embargo, la estrategia se verá desbordada debido a la propia especificidad de un espacio como el sudeste peninsular en el que confluirá una frontera múltiple formada por Aragón, Castilla y Granada, cuando los límites del Reino de Valencia se situaron a apenas 100 kilómetros del Reino de Granada tras la partición del Reino de Murcia que se decretó en los acuerdos de Torrellas-Elche (1304-1305). ${ }^{10}$ El carácter específico del citado espacio estaría marcado por la desarticulación o vacío poblacional que afectó al territorio murciano que quedó bajo dominio castellano, ${ }^{11}$ y por la compleja asimilación del elemento mudéjar que permaneció en territorio cristiano.

Tras las revueltas mudéjares en las comarcas murcianas y valencianas durante las décadas centrales del siglo XIII, además de la invasión del Reino de Murcia por parte de Jaime II a finales de la centuria, disminuyó el número de musulmanes en el sudeste peninsular. ${ }^{12}$ Los territorios castellanos se mostraron más proclives a la marcha de los musulmanes hacia territorio islámico, al fin y al cabo sus límites constituían la frontera con Granada por antonomasia, debido a que su intención era llevar a cabo una sistemática repoblación cristiana. Sin embargo, la llegada de colonos no alcanzó los niveles esperados como para poblar eficazmente el territorio, y la monarquía recurrió a las Órdenes Militares para vertebrar y defender las tierras murcianas, ${ }^{13}$ otorgándoles amplios sectores en torno al curso del río Segura, poblados por mudéjares que mantuvieron una amplia actividad agrícola, y en el centro del

9 JIMÉNEZ ALCÁZAR, J. F: "Gobernar fronteras: Poderes locales, dominio territorial y control central en la Castilla meridional (ss. XIII-XVI)", Edad Media: Revista de Historia, 14, (2013), p. 139.

10 JIMÉNEZ ALCÁZAR, J. F: "Et por estar esta tierra...", pp. 354-359. Los pactos de Torrellas-Elche deshacían el acuerdo alcanzado en Almizra en 1244, y que establecía los límites de la Corona de Aragón en la línea formada por Biar, Xixona y Vilajoyosa. Las aspiraciones expansionistas de los reyes de Castilla y de Aragón provocaban continuos incumplimientos, que requerían el restablecimiento de los límites y de las áreas de expansión. En 1151, el Tratado de Tudilén comprendía al Reino de Murcia en el área de expansión aragonesa, sin embargo en el Tratado de Cazola, 1179, perdía ese derecho a favor de Castilla.

11 JIMÉNEZ ALCÁZAR, J. F.: "Et por estar esta tierra...", p. 363.

12 FERRER I MALLOL, M ${ }^{a}$ T.: La frontera amb l'Islam..., p. 5; Véase LÓPEZ DE COCA CASTAÑER, J. E.: "Sobre la emigración mudéjar al Reino de Granada", Revista d'Història Medieval, 12 (2001-2002), pp. 241-258.

13 JIMÉNEZ ALCÁZAR, J. F.: "Et por estar esta tierra...", pp. 364-365. 
Adelantamiento (Totana, Aledo o Caravaca). ${ }^{14}$ En cuanto a señoríos solariegos en el Adelantamiento de Murcia, cabe destacar el marquesado de Villena, cuya vecindad con la Gobernación de Orihuela supuso una intensa actividad económica, ${ }^{15}$ pero también diplomática.

El caso de las futuras tierras de la procuración de Orihuela presenta matices ya que no sufrió un vacío poblacional severo y siguió manteniendo una amplia comunidad mudéjar en el valle del medio Vinalopó, así como importantes morerías urbanas como la de Elche. ${ }^{16}$ Pese a la reducción sufrida en distintas etapas, ${ }^{17}$ Jaime II desarrolló medidas repobladoras dirigidas a la población mudéjar, para así evitar a corto plazo la despoblación del territorio y la pérdida de una importante mano de obra, mientras que en paralelo se impulsaba una repoblación cristiana que resultó lenta, pero que equilibró la relación de fuerzas entre cristianos y musulmanes paulatinamente. ${ }^{18}$ El Reino de Valencia no compartía frontera directa con el Reino de Granada, pero la realidad fue que sus habitantes del sur del reino estuvieron expuestos a la coyuntura de intranquilidad e incertidumbre que caracterizaba a la múltiple frontera terrestre en el sudeste peninsular y a su fachada marítima. ${ }^{19}$ Con respecto al ámbito jurisdiccional, la Gobernación de Orihuela contaría en su interior, en el valle medio del Vinalopó, con numerosos señoríos solariegos o de la familia real, ${ }^{20}$ los cuales estarían principalmente poblados por mudéjares. ${ }^{21}$

14 VEAS ARTESEROS, F. de Asís: "El sureste en la Edad Media", Militaria, Revista de Cultura Militar, vol. 16 (2002), p. 45.

15 Véase HINOJOSA MONTALVO, J. R.: "El Marquesado de Villena frontera con el Reino de Valencia", Congreso de Historia del Señorío de Villena. Albacete, 23-26 octubre 1986, ed. Instituto de Estudios Albacetenses "Don Juan Manuel", Albacete, 1987, pp. 227-233.

16 Véase HINOJOSA MONTALVO, J. R.: La morería de Elche en la Edad Media, ed. Centro de Estudios Mudéjares, Teruel, 1994, 196 pp.

17 HINOJOSA MONTALVO, J. R.: "Las relaciones entre Elche y Granada (ss. XIV-XV). De Ridwan a la guerra de Granada", Sharq al-Andalus, 13 (1996), pp. 47-61.

18 FERRER I MALLOL, $\mathrm{M}^{\mathrm{a}} \mathrm{T}$.: La frontera amb l'Islam..., pp. 6-7.

19 HINOJOSA MONTALVO, J. R.: "El Reino de Valencia, frontera marítima entre Aragón y Granada", Actas del Congreso La frontera oriental nazarí como sujeto histórico (s. XIII-XVI), Pedro Segura Artero (coord.), Instituto de Estudios Almerienses, Almería, 1997, pp. 409-433; SALICRÚ I LLUCH, R.: "La frontera marítima en el Mediterráneo bajomedieval", III Estudios de Frontera. Convivencia, defensa y comunicación en la frontera. En memoria de don Juan de Mata Carriazo y Arrioquia. Alcalá la Real, 1999, ed. Diputación Provincial, Jaén, 2000, pp. 681-709.

20 Véase FERRER I MALLOL, $\mathrm{M}^{\mathrm{a}} \mathrm{T}$.: Les aljames sarraïnes de la governació d'Oriola en el segle XIV, CSIC-Institució Milà i Fontanals, Barcelona, 1988, 339 pp.

21 El profesor Guinot matiza que esta señorialización de los mudéjares no fue consecuencia de la conquista, sino que fue un fenómeno que se inició a principios del siglo XIV por interés de la clase dominante feudal (GUINOT, E.: "Los mudéjares de la Valencia medieval: renta y señorío", Áreas, 14 (1992), pp. 29-47). 
Estaríamos ante una situación de pluralidad de núcleos de poder, dando lugar, en palabras de Soler Milla y de Ortuño Molina, a una concepción del poder vista como un sistema de interacción en el que la negociación, la connivencia y la confrontación son inherentes. ${ }^{22}$ Tendríamos, por lo tanto, una frontera artificial entre dos núcleos de poder regional como el Adelantamiento de Murcia y la Gobernación de Orihuela que partían en dos una región natural como la vega del Segura, además de otras fronteras internas de índole jurisdiccional (real y señorial). Desde otro punto de vista, como el étnico-religioso, tendríamos que hablar de una frontera interna entre la comunidad cristiana y musulmana en estas regiones, a tener en cuenta por las implicaciones identitarias, ideológicas y jurisdiccionales que van a presentar en relación con las problemáticas vinculadas al espacio rayano del sudeste peninsular.

Se trata, por lo tanto, de un espacio marcado por unas intensas relaciones familiares, vecinales y económicas, en definitiva, por unas necesidades vitales, que superarán los distintos marcos jurisdiccionales, ${ }^{23}$ y que harán de la frontera, retomando de nuevo las reflexiones de Bazzana, una membrana viva. ${ }^{24}$ La sociedad resultante en el sudeste peninsular experimentará unos fenómenos potenciados y atrofiados por el propio carácter de esa sociedad. La actividad violenta y sus consecuencias, principalmente el cautiverio, determinarán la vida en la frontera, y provocarán una reacción en los distintos grupos de poder y en las comunidades que se materializará en instituciones arbitradoras o pactos para resolver los conflictos y perjuicios que esa actividad acarreaba. ${ }^{25}$ Sin embargo, se debe reconsiderar la eficacia de esos acuerdos para reprimir el fenómeno violento por estar supeditados a esa concepción del poder que implicaba una compleja relación de interacción entre distintos agentes de poder.

22 ORTUÑO MOLINA, J; SOLER MILLA, J. L.: "Espacio jurisdiccional y espacio económico en el Sureste Peninsular en la Baja Edad Media" Journal of Medieval Iberian Studies, 6/1 (2009), p. 69.

23 Ibídem, p. 76. VEAS ARTESEROS, F. de Asís: "El sureste...", p. 41. Como señala Juan Antonio BARRIO BARRIO, entre los siglos XIV y XV las migraciones de corto radio fueron la tónica general en el área murciana y oriolana. Los migrantes avecindados en Orihuela en este periodo provenían principalmente de las comarcas castellanas rayanas ("Inmigración, movilidad y doblamiento urbano en un territorio de frontera. La gobernación de Orihuela afines del Medievo", Revista d'Història Medieval, 10 (1999), p. 2015.

24 BAZZANA, A.: art. cit., p. 31.

25 ORTUÑO MOLINA, J.: art. cit., p. 88. 


\section{LOS AGRAVANTES DEL FENÓMENO DE LA VIOLENCIA}

La fijación de una frontera múltiple en el sudeste peninsular convirtió a dicho espacio en el termómetro de las relaciones diplomáticas entre las tres soberanías que coincidían en él, así como en la principal base desde donde jugar sus cartas en la intensa pugna geopolítica que mantenían. ${ }^{26}$ El fenómeno de la violencia, desde un punto de vista diplomático y geopolítico, era una de esas cartas. Y los agentes diplomáticos y redentores, los espías, las tropas, los bandidos y los cautivos los actores de un juego en el que cada uno interpretaba un rol predeterminado. De modo que la intensidad, cuando no ansiedad, en el espacio rayano era elevada por la permanente actividad que el juego fronterizo generaba.

La vida en una sociedad de frontera implicaba una serie de peligros propios de dicha sociedad, pero sin que se debamos aventurarnos a presentar una frontera más violenta que los espacios no limítrofes. La frontera refleja una realidad fluctuante en la que la coexistencia pacífica o violenta se entrecruza o alterna en los episodios cotidianos que los habitantes de la misma tejen en su día a día. En el mismo orden, las autoridades municipales y regionales, con sus órganos de justicia, van a regular y a juzgar los episodios violentos, con más o menos eficacia por las fallas que producía la dinámica de interacción entre distintas jurisdicciones, pero sin permitir que la frontera fuera un espacio con una justicia poco estricta. ${ }^{27}$ Diferente es que determinados individuos supieran aprovechar las facilidades que daba la frontera para la huida y el encubrimiento, como la yuxtaposición de jurisdicciones y la existencia de sectores despoblados, para la consecución de sus objetivos y escapar de la ley. ${ }^{28}$

A pesar de ello, el papel de las autoridades municipales resultó crucial para el gobierno y defensa del espacio fronterizo. El carácter periférico del mismo, es decir, la lejanía del centro de poder del reino, y la necesidad de resolver con celeridad cuestiones urgentes ${ }^{29}$ dotó a las autoridades munici-

26 CABEZUElO PliEGO, J. V.: "Guerra y violencia...", p. 48; MENJOT, D.: "Urbanización fronteriza y control del espacio en la Corona de Castilla en la Baja Edad Media", Dominar y controlar en Castilla en la Edad Media, Denis Menjot, ed. Diputación de Málaga, Málaga, p. 124.

27 JIMÉNEZ ALCÁZAR, J. F.: "Et por estar esta tierra...", p. 389.

28 ORTUÑO MOLINA, J.; SOLER MILLA, J. L.: art. cit., p. 71; CABEZUELO PLIEGO, J. V.: "El negocio del rapto en la frontera de Orihuela a principios del siglo XIV", Miscelánea Medieval Murciana, vol. XXI-XXII (1997-1998), p. 44.

29 JIMÉNEZ ALCÁZAR, J. F: "Relaciones interterritoriales en el sureste de la Península Ibérica durante la Baja Edad Media: Cartas, mensajeros y ciudades en la frontera de Granada", Anuario de Estudios Medievales, 40/2 (2010), p. 599. 
pales de autonomía y competencias para articular la defensa y las relaciones interterritoriales con los territorios colindantes, sin que ello supusiera no seguir las líneas del proyecto político de la Corona, ya que fueron su principal soporte. ${ }^{30}$ De este modo, tal y como señala Jiménez Alcázar, el concejo o consell se consolidó como representante de la autoridad monárquica en el ámbito de las relaciones fronterizas o interterritoriales. ${ }^{31}$

Las relaciones que mantuvo la Gobernación de Orihuela con sus vecinos (Murcia, Lorca y Villena en Castilla; Vera y Vélez en Granada) estuvieron condicionadas por situaciones que no hacían más que agravar el fenómeno violento. Las comarcas orientales del Reino de Granada, con Vera y Vélez como principales plazas, fueron uno de los puntos de tensión, tanto por las razzias contra territorio cristiano que se lanzaban desde aquí como por las réplicas en dirección opuesta, entre finales del siglo XIV y principios del XV. Esta inestabilidad desataba los rumores de guerra, motivando que el gobernador de Orihuela mandara reparar los castillos de su jurisdicción ante un posible ataque del rey de Granada. ${ }^{32}$ Pero las relaciones diplomáticas mejorarían durante los primeros años del cuatrocientos, cuando los soberanos aragonés y granadino trataron de mejorar las relaciones entre sus reinos con la firma de un tratado de paz en 1405 que tendría una vigencia de cinco años. ${ }^{33}$

La actividad violenta perpetrada por los granadinos se recrudeció por el apoyo que recibían de los mudéjares valencianos, hecho que aumentó la desconfianza hacia la comunidad mudéjar y generó cierta neurosis. ${ }^{34} \mathrm{La}$ inserción de los mudéjares en la sociedad cristiana se basaba en una relación de dominio y marginación, y al ser una comunidad numerosa con una religión y costumbres distintas y extrañas, coincidentes con las prácticas de los granadinos y norteafricanos, en una desconfianza y tensa coexistencia alimentada por la ideología dominante que emanaba del poder civil y de la Iglesia.

30 JIMÉNEZ ALCÁZAR, J. F: “Gobernar fronteras...", p. 143, p. 148; LÓPEZ GARCÍA, J. C.: "El gobierno municipal de una villa de frontera: dominio y defensa del territorio y relaciones exteriores Orihuela (s. XV)", Roda da Fortuna: Revista Electrônica sobre Antiguidade e Medievo Actas del III Congreso Internacional de Jóvenes Medievalistas Ciudad de Cáceres Ciudad y cultura política urbana en la Edad Media, v. 4, nª 1-1(2015), p. 202.

31 JIMÉNEZ ALCÁZAR, J. F: "Relaciones interterritoriales...", p. 590.

32 FERRER I MALLOL, $\mathrm{M}^{a}$ T.: La frontera amb l'Islam..., p. 178.

33 Ibidem, p. 181; Para las relaciones diplomáticas entre la Corona de Aragón y el Reino de Granada, véase SALICRÚ I LLUCH, R.: El Sultanat de Granada i la Corona d'Aragó, 1410-1458, CSIC-Institució Milà i Fontanals, Barcelona, 1998, 560 pp.; El sultanato nazarí de Granada, Génova y la Corona de Aragón en el siglo XV, Universidad de Granada, Granada, 2007, 366 pp.

34 LÓPEZ DE COCA CASTAÑER, J. E.: "Los mudéjares valencianos y el reino nazarí de Granada”, En la España Medieval, 2 (1982), p. 645. 
Los reinos musulmanes eran considerados enemigos del rey y del catolicismo, y los seguidores del Islam infieles, ya que suponían una realidad política y religiosa opuesta, percepción que a la inversa coincidiría. ${ }^{35}$ Cabe señalar que los mudéjares se sentirían parte de una colectividad supranacional y religiosa, por lo que existiría cierta solidaridad panislámica ${ }^{36}$ que se plasmaría en el papel de quintacolumna que parte de la sociedad mudéjar adoptó. ${ }^{37}$ Sin embargo, el poder civil mantendría una posición ambigua con respecto a su relación con sus vasallos musulmanes y su pensamiento. ${ }^{38} \mathrm{El}$ poder religioso resultó ser menos ambiguo y los predicadores exhortaban a las autoridades a cristianizar el reino, controlar a los mudéjares y a impedir que el nombre de aquell malvat Mahoma fuera honrado públicamente. ${ }^{39}$

A finales del siglo XIV, combatir el quintacolumnismo ya presentaba trabas incómodas por esa multiplicidad de jurisdicciones existente. En noviembre de 1383, las autoridades de Orihuela comunicarían a las de Elche, a través de un mensajero, que el rey Pedro IV había comprado los lugares del valle de Elda para cedérselos a la reina consorte, Sibila, ante lo cual ordenaba que el gobernador no se entrometiera en dichos lugares bajo ningún concepto, ni tan siquiera por causa de collera. ${ }^{40}$ El mensajero expuso que el gobernador tenía competencias para intervenir en dichos casos, y que si dejaba de ser así causaría grandes perjuicios en la tierra por los delitos que cometían los almogávares granadinos con apoyo de los moros del valle de

35 Aunque la idea del enemigo en el espejo la acunó R. BARKAI (Cristianos y musulmanes en la España Medieval (el enemigo en el espejo), ed. Rialp, Madrid, 1984), para este trabajo hemos consultado las aportaciones de $\mathrm{M}^{\mathrm{a}} \mathrm{J}$. RUBIERA MATA ("El enemigo en el espejo. Percepción mutua de cristianos y musulmanes", Cristiandad e Islam en la Edad Media hispana. XVIII Semana de Estudios Medievales, José I. de la Iglesia Duarte (coord.), ed. Instituto de Estudios Riojanos, Logroño, 2008, pp. 355-370).

36 HINOJOSA MONTALVO, J. R.: "Musulmanes en los reinos cristianos: una desconfianza permanente", Cristiandad e Islam en la Edad Media hispana, José I. de la Iglesia Duarte (coord.), Instituto de Estudios Riojanos, Logroño, 2008, p. 343.

37 M. MARTÍNEZ CARRILLO, para el caso de la comunidad mudéjar murciana, afirma que el "comportamiento en ocasiones traicionero, no respondía exclusivamente a motivos de solidaridad religiosa...; su situación de pobreza se veía afectada por las cargas tributarias a las que no podían hacer frente..." (Revolución urbana y autoridad monárquica en Murcia durante la Baja Edad Media (1395-1420), Universidad de Murcia, Murcia, 1980, p. 65).

38 Véase BARRIO BARRIO, J. A.: "La difícil convivencia entre cristianos y musulmanes en un territorio fronterizo. La gobernación de Orihuela en el siglo XV", Sharq alAndalus, 13 (1996), pp. 9-26.

39 FERRER I MALLOL, $\mathrm{M}^{\mathrm{a}} \mathrm{T}$.: "Frontera, convivencia y proselitismo entre cristianos y moros en los textos de Francesc Eiximenis y de San Vicente Ferrer", Pensamiento medieval hispano, José María Soto Rábanos (coord.), CSIC, Barcelona, 1998, v. 2, p. 1584.

40 Crimen que consistía en el secuestro de individuos para su venta como cautivos $u$ obtener el pago de un rescate. 
Elda, por lo que el consell de Orihuela había decidido escribir una carta de protesta al rey. El consell de Elche, una vez reflexionada la postura de Orihuela, decidió escribir a su señor en esa época, el infante don Martín, para que intercediera ante su padre. ${ }^{41}$

Cabe señalar que el mensajero de Orihuela haría mención durante su intervención de un caso reciente en el que dos cristianos, llamados Johan de Fontes y Pero Ferrandez, habían sido cautivados en el portichol d'Alacant y escondidos en Novelda por moros de dicho lugar. Según el cronista mosén Pedro Bellot, los responsables del asalto fueron un total de once moros que posteriormente trasladaron a los cautivos desde Novelda a Aznalacet, situado en el Reino de Granada, donde permanecieron hasta que obtuvieron la libertad, y para lo cual tuvieron que empeñar gran parte de su hacienda. Las consecuencias que derivaron de este suceso evidencian la tensa coexistencia que en ocasiones se vivía entre cristianos y musulmanes en la Gobernación de Orihuela, pues los vecinos de Elche y de Alicante respondieron con ataques contra la huerta y los corrales de Novelda, además de otros lugares del valle como Elda y Aspe. ${ }^{42}$

Los señores, así como sus procuradores, se mostrarían generalmente permisivos y protectores con sus vasallos mudéjares, entorpeciendo así las labores de justicia contra las muertes y cautiverios en los que participaban. Dicha situación se complicaba cuando los mudéjares implicados en agresiones contra cristianos de la Gobernación provenían de encomiendas de órdenes militares del Adelantamiento de Murcia, ya que ello podía suponer la necesidad de la mediación del adelantado debido a la actitud connivente con los bandidos de los procuradores de las encomiendas frente a las autoridades valencianas.

Con la Corona de Castilla se vivía en concordia desde el final de la guerra de los dos Pedros, aunque con altibajos puntuales que deterioraron las relaciones..$^{43} \mathrm{El}$ contacto entre ambas coronas en el ámbito de la frontera del sudeste peninsular estuvo marcado por los asaltos recíprocos protagonizados por almogávares, la ayuda mutua ante la amenaza granadina ${ }^{44} \mathrm{y}$ las intensas

41 A(rchivo).M(unicipal).E(lche). Libros de ordenaciones del Consell, 1, ff. 312r-314r.

42 BELlOT, P: Anales de Orihuela, ed. Juan Torres Fontes, Real Academia Alfonso X el Sabio, Murcia, 2001, v. 1, pp. 159-160.

43 Véase FERRER I MALLOL, M ${ }^{a}$ T.: Entre la paz y la guerra. La Corona Catalano-Aragonesa y Castilla en la Baja Edad Media, CSIC-Institució Milà i Fontanals, Barcelona, 2005, 662 pp.

44 Véase FERRER I MALLOL, M ${ }^{a}$ T.: Organització i defensa d'un territori fronterer. La governació d'Oriola en el segle XIV, CSIC-Institució Milà i Fontanals, Barcelona, 1990, 631 pp.; LÓPEZ GARCÍA, J. C.: art. cit., pp. 17-18. 
relaciones vecinales, laborales y comerciales que mantenían las comarcas rayanas. ${ }^{45}$ Los contactos más intensos se mantenían con Murcia y Lorca, ya que la primera era la capital del adelantamiento y la segunda la principal plaza fronteriza en el sudeste peninsular por su proximidad al Reino de Granada. ${ }^{46}$ Pero el marquesado de Villena estaría igualmente muy conectado con Orihuela por los incidentes entre mudéjares del interior de la Gobernación y castellanos de Villena y de Sax.

El robo y el secuestro por parte de hombres de los distintos reinos o comunidades presentes en la frontera resultó ser un negocio muy rentable. ${ }^{47}$ En el caso del cautiverio podían obtener grandes beneficios por dos vías, la venta del cautivo como esclavo o la liberación a cambio de un rescate. La presencia de una comunidad o minoría religiosa sometida en territorio cristiano propició que los mudéjares fueran las víctimas preferidas de los bandidos cristianos, que actuarían generalmente en el territorio vecino para zafarse de la justicia, ya que constituían una presa fácil con la que obtener ganancias rápidamente.

Debido a los daños y pérdidas que se producían en la frontera castellanovalenciana, en diciembre de 1416 se anunció por todo el Reino de Valencia la decisión de imponer el pago de 3 dineros por libra de dineros sobre todas las ropas y mercaderías que cruzaran la frontera en ambas direcciones entre la Corona de Castilla y el Reino de Valencia, con el objeto de indemnizar a los valencianos damnificados por súbditos del rey de Castilla en tiempo de paz. ${ }^{48}$

La violencia, por lo tanto, estaba ramificada por todo el territorio fronterizo, perjudicando e implicando a las comunidades de los distintos espacios jurisdiccionales. Así pues, las distintas comunidades reaccionaron estableciendo lazos de colaboración mediante pactos o instituciones arbitradoras que paliaran los efectos de la violencia. La permanente comunicación a dos o a tres bandas entre castellanos, valencianos y granadinos, ${ }^{49}$ así como entre la comunidad cristiana y musulmana, fructificaría en el establecimiento de acuerdos de ese tipo, ${ }^{50}$ pero en algunos casos deberíamos replantearnos la eficacia de los mismos y analizar las dificultades que se encontraron.

45 ORTUÑO MOLINA, J.; SOLER MILLA, J. L.: p. 78.

46 JIMÉNEZ ALCÁZAR, J. F: "Relaciones interterritoriales", pp. 581-582.

47 CABEZUELO PLIEGO, J. V. "El negocio del rapto...", p. 53.

48 A.M.E. Libro de ordenaciones del Consell, 3, ff. 292r-294r.

49 Véase JIMÉNEZ ALCÁZAR, J. F: "Relaciones interterritoriales...", pp. 565-602.

50 Véase TORRES FONTES, J.: "El alcalde entre moros y cristianos del Reino de Murcia", Hispania: Revista española de historia, 78 (1960), pp. 55-80; LÓPEZ GARCÍA, J. C.: art. cit, pp. 11-12. 


\section{VILLAS CRISTIANAS Y ALJAMAS MUSULMANAS COLABORANDO CONTRA LA VIOLENCIA}

Los años finales del siglo XIV, como ya hemos comentado, estuvieron marcados por las tensas relaciones y las frecuentes agresiones entre el sur del Reino de Valencia y las comarcas orientales del Reino de Granada, así como por el apoyo que los mudéjares valencianos prestaron a los granadinos y por las agresiones que éstos a su vez sufrían. Esta situación obligó a las comunidades cristiana y mudéjar de la Gobernación de Orihuela a buscar soluciones conjuntas para atajar el problema, como la hermandad para la restitución de las víctimas y la represión de la violencia. Las universidades cristianas se encargarían de restituir a los mudéjares víctimas de almogávares cristianos, y las aljamas mudéjares harían lo propio con los cristianos atacados por musulmanes.

La Hermandad estuvo vigente entre 1399 y 1410, aunque hubo un antecedente en 1394. Según la profesora Ferrer i Mallol, los capítulos de 1394 fueron recuperados para el acuerdo de 1399 y se introdujeron algunas novedades, como la valoración de los casos de homicidio. ${ }^{51}$ Sin embargo, la descripción de los capítulos por parte de la profesora Ferrer i Mallol no coincide totalmente con los capítulos conservados en el Archivo Municipal de Elche. ${ }^{52}$ Ferrer i Mallol afirma que si la víctima era extranjera se destinaría la mitad de la indemnización a los herederos y la otra mitad al rey o al señor del lugar en el que se hubiera cometido el delito, ${ }^{53}$ pero en el citado documento se dice literalmente, para el caso de un cristiano extranjero: “...e si sera stranger a les universitats de cristians la meytat e l'altra meytat al senyor Rey o al senyor de la vila o del loch en lo terme del qual sera fet lo malefici”. [Y para el caso de un musulmán extranjero] “...e si sera stranger a les dites aljames de moros la meytat e l'altra meytat al senyor Rey o al senyor de la vila o del loch en lo terme del qual sera fet lo malefici". ${ }^{54}$

Otra diferencia que advertimos entre el documento ilicitano y la exposición de Ferrer i Mallol sobre los capítulos de 1394 tiene que ver con el plazo para rescatar a los cautivos. Ferrer i Mallol afirma que en los capítulos de 1394 el plazo era de seis meses, pero si el cautivo se encontraba en un

51 FERRER I MALLOL, Ma T.: La frontera amb l'Islam..., p. 205.

52 A.M.E., Pergamino 38, 19/12/1399.

53 FERRER I MALLOL, M ${ }^{a}$ T.: La frontera amb l'Islam..., pp. 198-199.

54 Según Juan TORRES FONTES, la mitad de la indemnización pertenecería al rey o al señor de la villa en cuyo término se hubiera cometido el delito y la otra mitad para su consejo ("La Hermandad de moros y cristianos para el rescate de cautivos", Actas del I Simposio Internacional de Mudejarismo, Instituto de Estudios Turolenses, Teruel, 1981, pp. 501-502). 
lugar lejano el Gobernador establecería el plazo. ${ }^{55}$ Sin embargo, tal y como ya hemos mencionado, en 1399 se establecería un plazo de tres meses para rescatar a individuos retenidos en territorios próximos y un plazo de seis meses si se encontraban en espacios más alejados.

La Hermandad generó en sus primeros meses de vida grandes expectativas. Por un lado, las villas cristianas de la Gobernación se dirigieron al comisario regio que se había encargado de garantizar la firma de los capítulos, Guillem Martorell, para que se negociase la inclusión en la misma del Adelantamiento de Murcia y del Marquesado de Villena. Con respecto a Murcia se aducía a los lazos de vecindad que existían, y en cuanto a Villena a los daños que desde dicho territorio recibía la Gobernación de Orihuela. El marquesado llegó a pedir licencia al rey de Castilla para integrarse en el pacto, pero la autorización se retrasó y no fue posible. Y por otro lado, los mudéjares comenzaron a optar por no facilitar ayuda a los granadinos y por llamar al apellido cuando éstos atacaban, para así evitar el pago de sus posibles daños. Sin embargo, las entradas desde el Reino de Granada no cesaron, ${ }^{56}$ siguió habiendo acusaciones de quintacolumnismo, y las agresiones entre los espacios castellano y valenciano no hicieron más que confirmar la necesidad de incluir a las tierras murcianas en la Hermandad.

En abril de 1400 fueron secuestrados en el término de Aspe dos trajineros de Villena por moros del valle. Las autoridades municipales de la Gobernación se apresuraron a exigir a las aljamas musulmanas que rescatasen a los cautivos y que dejasen de prestar apoyo a los ladrones granadinos, ya que temían que Villena efectuase una represalia contra los moros del valle que, en virtud de los capítulos de la Hermandad, deberían pagar los cristianos. Pero las aljamas respondieron que, según los capítulos, no estaban obligados a buscar y a restituir a los dos hombres de Villena secuestrados. ${ }^{57} \mathrm{Y}$ es que en los capítulos correspondientes al rescate de cautivos, tanto cristianos como musulmanes, sólo se hace referencia a miembros de la señoría del rey de Aragón, no a víctimas extranjeras. Como ya hemos apuntado, en caso de homicidio sí se contemplaba la indemnización por víctimas extranjeras, ${ }^{58}$ supuesto que fue eliminado en los capítulos de 1402.

En sentido contrario, el procurador de Elda y Aspe había denunciado ante el lugarteniente de Gobernador un asalto sufrido por cuatro moros de

55 FERRER I MALLOL, M ${ }^{a}$ T.: La frontera amb l'Islam..., pp. 198-199.

56 BELLOT, P.: op. cit., p. 185.

57 NIETO FERNÁNDEZ, A.: Orihuela en sus documentos IV. Musulmanes y judíos en Orihuela (siglos XIV-XVIII), Instituto Teológico Franciscano, Murcia, 1997, pp. 110-111.

58 A.M.E., Pergamino 38, 19/12/1399. 
Aspe el 30 de diciembre de 1400, exigiendo por ello la resolución por parte de las universidades de cristianos según los capítulos. Hamet, Abraham, Edam y Cereig estaban cazando en la montaña cuando fueron atacados por unos bandidos castellanos. Los malhechores lograron hacer un cautivo, Hamet, y mataron a Edam y a Cereig, siendo Abraham el único que pudo escapar de ellos. ${ }^{59}$ Las universidades de cristianos estaban obligadas a pagar 1200 sueldos por cada víctima mortal, ${ }^{60}$ cantidad que pertenecería a sus herederos, como en el caso de Cereig, ${ }^{61}$ o a la aljama en caso de que no los tuviera.

Con respecto a Hamet, fue buscado y rescatado por un jurado de Orihuela, llamado Johan de Orumbella, ${ }^{62}$ por 119 florines y 3 sueldos entre marzo y abril de 1401, por lo que se cumplieron los plazos. El dinero para los gastos y gestiones derivados del rescate fue adelantado por la villa de Orihuela, que presentó un pleito, ante el lugarteniente de Gobernador, a Elche y a Alicante por las cantidades que Orihuela les reclamaba. ${ }^{63}$

En los capítulos se introducirían otras disposiciones para controlar los niveles de violencia y restringir ciertas operaciones que contribuirían a evitar tensiones mayores entre la Corona de Aragón y el Reino de Granada, en unos años en los que no había acuerdo de paz o tregua alguna entre ambos reinos. En el pacto de 1399 no se contemplaba la reparación de víctimas caídas en marcas o represalias efectuadas en el marco de la Gobernación de Orihuela y del Adelantamiento, desprotegiendo así a quienes participaran en ellas. Y para contrarrestar el negocio de la compra-venta de cautivos, se decidió que los cristianos no compraran moros de Granada si no iban a ser canjeados por vecinos de la Gobernación cautivos. El 7 de enero de 1401, los

59 A.M.E. Libro de ordenaciones del Consell, 2, ff.86r-88r. Nieto, 139.

60 Los capítulos establecían que Elche y Alicante, así como sus aldeas, pagarían una quinta parte cada una de la indemnización, y Orihuela, junto a sus aldeas, las tres partes restantes. En la indemnización por la muerte de Cereig, Elche recaudó, durante la primavera de 1401, 205 sueldos y 8 dineros aportados por los varones mayores de 15 años y las viudas no miserables. A Elche también le correspondió recaudar las aportaciones de los lugares del valle y de Salina, que sumaron 34 sueldos y 8 dineros (A.M.E. Libro de ordenaciones del Consell, 2, ff. 135r-138r). La suma de ambas cantidades corresponden a una quinta parte de 1200 sueldos.

61 A.M.E. Libro de ordenaciones del Consell, 2, ff. 124r-128v.

62 Orumbella estuvo durante más de cuarenta días viajando para resolver este suceso, así como otro incidente que sufrieron otros dos moros de Aspe en la sierra de Crevillente. En Murcia encontró a uno de los implicados, que fue torturado para sustraerle información y posteriormente ejecutado (NIETO FERNÁNDEZ, A.: Orihuela en sus documentos..., p. 128). A Villena y a Catral también se desplazaría para recoger testimonios de testigos (NIETO FERNÁNDEZ, A.: Orihuela en sus documentos..., pp. $139-140$ y 154).

63 A.M.E. Libro de ordenaciones del Consell, 2, ff. 163r-164r. 
jurados de Orihuela compraron dos moros al almogávar Andrés de Benavent para emplearlos en el rescate de vecinos de la villa. Sin embargo, el consell decidiría ese mismo día plantearle al lugarteniente de Gobernador y a los jurados que no dieran licencias ni consintieran que los almogávares entraran a tierra de moros a secuestrar o a rescatar cautivos durante la vigencia de la Hermandad. ${ }^{64}$

Esa petición no fue atendida, ya que se siguieron dando licencias, tanto por parte del lugarteniente de Gobernador como del Consell, para tomar prendas en el Reino de Granada con el fin de canjearlos por cristianos cautivos. ${ }^{65}$ Una vez superados los dos años de vigencia de los capítulos de 1399, se negoció un nuevo acuerdo que sí incluía, además de la restricción en la compra-venta de moros, la prohibición de realizar marcas, estando estas disposiciones sujetas a la voluntad del Consell, siempre y cuando se realizaran para rescatar a cristianos caídos en cautiverio antes de la firma de la Hermandad.

Pero la renovación de la Hermandad no fue sencilla por las diferencias que salieron a la luz entre las villas cristianas y las aljamas musulmanas. Durante el mes de diciembre de 1401, representantes de los lugares de señorío, así como los representantes de la comunidad mudéjar, se dirigieron a los consells de Orihuela ${ }^{66}$ y Elche ${ }^{67}$ para mostrar su predisposición a renovar el pacto, ya que consideraban que había dado buen resultado y para evitar una nueva y costosa intervención de un comisario regio. Las autoridades de Orihuela se mostraron reacias a la renovación ${ }^{68}$ y desafiantes ante la posibilidad de una nueva intervención real, ya que se negaban a ser forzados a firmarla.$^{69}$ En cualquier caso, las villas cristianas emplazaron su respuesta a las aljamas y a sus procuradores hasta que se hubieran reunido, por lo que entre ellas comenzaron las conversaciones para organizar una reunión con el fin de determinar una postura común sobre la hermandad. ${ }^{70}$

El 8 de enero de 1402 se produjo la tan esperada reunión, y los representantes de Orihuela, Elche y Alicante plantearon una serie de correcciones en los capítulos anteriores, acordando que aceptarían la renovación de los mismos si introducían sus propuestas. Los principales cambios que propusieron

64 NIETO FERNÁNDEZ, A.: Orihuela en sus documentos..., p. 127.

65 Ibídem, pp. 130 y 149.

66 A(rchivo).M(unicipal).O(rihuela). Actas capitulares,10, sin foliar, 11 de diciembre de 1401; A.M.O. Actas capitulares, 6v.

67 A.M.E. Libro de ordenaciones del Consell, 2, ff. 231r-232v.

68 NIETO FERNÁNDEZ, A.: Orihuela en sus documentos..., p. 138.

69 A.M.O. Actas capitulares, 10, sin foliar, 11 de diciembre de 1401.

70 A.M.O Actas capitulares, 12, f. 6r-6v. 
fueron los siguientes: ${ }^{71}$ Primero, que la indemnización por víctima cristiana se aumentase de 2000 sueldos a 4000 . Y la indemnización por víctima musulmana de 1200 sueldos a 2000. Los 4000 sueldos por víctima cristiana serían percibidos a partes iguales por sus herederos y su universidad, lugar o villa de origen. Y los 2000 sueldos por víctima musulmana serían percibidos a partes iguales entre sus herederos y su aljama de origen. Y si no tenían herederos, la mitad de la indemnización recaería en los justicias de su villa de origen, si la víctima era cristiana, o en el señor de su lugar de origen, si era musulmana. Y segundo, consideraron que la hermandad debía renovarse por tan solo un año en lugar de dos.

Las aljamas no aceptaron estas propuestas, en primer lugar porque el aumento de la indemnización les perjudicaba económicamente, y en segundo lugar porque querían que se renovara por otros dos años, por lo que mostraron su disconformidad a las villas cristianas. Sin embargo, éstas lanzaron el órdago de que si no aceptaban sus modificaciones la hermandad quedaría deshecha. ${ }^{72}$ Las negociaciones quedaban así al borde del colapso y las aljamas se dirigieron al rey denunciando la situación, logrando que Martín I ordenara al gobernador don Olfo de Proxida que interviniera a favor de la renovación de la Hermandad. ${ }^{73}$ El gobernador amenazó a las villas cristianas con una multa de 1000 florines de oro si no firmaban los capítulos. Ante eso, la villa de Orihuela escribió tanto al rey como al gobernador mostrando su repulsa a una posible multa y a ser forzados a firmar.

Sin embargo, el gobernador estaba llevando en paralelo otras negociaciones con el doctor en leyes Juan Rodríguez de Salamanca para integrar en la Hermandad a Villena y a Sax. ${ }^{74}$ Las villas cristianas vieron con muy buenos ojos este avance, pero se mantuvieron firmes en sus propuestas y exigieron la revocación de la amenaza de multa. ${ }^{75}$ Los enfrentamientos entre cristianos del marquesado y moros del valle marcaron las negociaciones, ya que la villa de Villena se dirigió a la villa de Orihuela con motivo de cuatro vecinos de Villena que habían entrado en el valle para vengar a unos parientes y que cayeron cautivos en el intento. Villena pedía que intercedieran ante el gobernador para que no castigara a sus vecinos hasta que se resolviese su entrada

71 A.M.O. Actas capitulares, 12, ff. 11r-15v.

72 A.M.O. Actas capitulares, 12, ff.25r-25v.

73 NIETO FERNÁNDEZ, A.: "Hermandad entre las aljamas de moros y las villas de la gobernación de Orihuela en el siglo XV", I Congreso de Historia del País Valenciano, Universidad de Valencia, Valencia, 1980, v. II, p. 754.

74 Ibídem, pp. 754-755.

75 A.M.O. Actas capitulares, 10, 1 de mayo de 1402. 
o no en la Hermandad, petición a la que accedió de buen grado Orihuela. ${ }^{76}$ Finalmente, el 9 de mayo, el gobernador lograría sentar a todas las partes, incluidas Villena y Sax, para negociar unos nuevos capítulos. Pero la tensión en los días previos sacó a la luz deficiencias en el funcionamiento de la hermandad. Las autoridades de Elche denunciarían en una carta dirigida al gobernador que las aljamas no habían pagado todavía los 4000 sueldos correspondientes a la indemnización por la desaparición de Miguel Galbiç y su hijo. ${ }^{77}$ El niño había desaparecido en las inmediaciones del Cap de l'Aljub durante una jornada de recreo familiar a finales de julio de $1401,{ }^{78}$ y Miguel cayó cautivo posteriormente, sin que nos conste la fecha de ello. ${ }^{79} \mathrm{Su}$ esposa quedó en condición de viuda y miserable al desaparecer él, y ante la pasividad latente se dirigió al consell de Elche a finales de noviembre para que tratara de localizar el paradero de sus familiares y, en caso de seguir vivos, rescatarlos. El consell atendió su petición y envió a un exea a la frontera de Granada, además de proceder a la consulta de los capítulos para determinar cómo podía resolverse este caso. ${ }^{80}$

Si el niño había desaparecido el 23 de julio de 1401, en noviembre ya se había cumplido el plazo de tres meses que tenían las aljamas para buscar y restituir a la víctima en caso de encontrarse en territorio granadino, por lo que éstas habrían desatendido su responsabilidad. En ese caso el consell de Elche, según los capítulos, podría haber exigido a las aljamas el envío de un exea que procediera a su búsqueda. Incluso haber elevado quejas al gobernador para que presionara a las aljamas o las penalizara por su incumplimiento, pero no constan movimientos de ese tipo en relación a esta desaparición. El resultado de las pesquisas del exea que envió Elche a finales de noviembre no lo conocemos, pero si atendemos a sus quejas en las vísperas de la reunión del 9 de mayo de 1402 para renovar la Hermandad, éste habría determinado la desaparición de padre e hijo, por lo que las aljamas estaban obligadas a pagar 2000 sueldos por cabeza.

Retomando la citada reunión del 9 de mayo de 1402, las partes lograron un equilibrio que colmase sus aspiraciones y garantizase su libertad a sumar-

76 NIETO FERNÁNDEZ, A. "Hermandad entre...", pp. 166-167.

77 A.M.E. Libro de ordenaciones del Consell, 2, ff. 303v-306r.

78 Horas después de su desaparición se sumaron vecinos de Elche, incluidos musulmanes, a la búsqueda del niño, hecho que evidencia la colaboración de la comunidad mudéjar junto a la cristiana en el contexto de la hermandad (A.M.E. Libro de ordenaciones del Consell, 2, ff. 171r-173v).

79 A primeros de agosto compadecía ante el Consell con relación a la desaparición de su hijo (A.M.E. Libro de Ordenaciones del Consell, 2, ff. 171r-173v).

80 A.M.E., Libro de ordenaciones del Consell, 2, ff. 229v-230r. 
se al acuerdo, tras reconocerse el respeto de las jurisdicciones, franquezas y libertades de las partes implicadas, y acordar que se rompería el mismo si no se revocaba la advertencia de multa en el plazo de tres meses. Los capítulos fueron en gran medida iguales a los de 1399 y se renovaron por dos años, pero resultaron más completos y se introdujeron algunas modificaciones importantes. Por un lado, el plazo para rescatar a un cautivo se elevaba de tres a seis meses, independientemente del lugar en el cual se encontrase. Y por otro lado, se mantenía la cuantía de las indemnizaciones, pero éstas se repartirían a partes iguales entre los herederos de la víctima y la villa o aljama de origen de ésta. ${ }^{81}$

En las siguientes ampliaciones de la hermandad no hubo grandes contratiempos, pero el rey Martín I y la reina Violante, señora de Elda, Novelda, Aspe y la Mola, no dudaron en estar atentos al desarrollo de la Hermandad y mostrar su apoyo a la renovación de la misma. ${ }^{82}$ Las resoluciones de casos en el marco de la Hermandad no fueron siempre positivos. Tenemos casos como el de dos moros de Albatera que en noviembre de 1403 fueron llevados presos a Cartagena, ${ }^{83}$ y cuyo caso se resolvió favorablemente con el rescate de ambos por 200 florines. ${ }^{84}$ Pero en otras ocasiones, y de nuevo por parte de las aljamas, la resolución de un caso caía en saco roto. El 15 de agosto de 1404, Pere Grimaldos, vecino de Orihuela, una mujer de Orihuela y Alfonso Fontes, vecino de Elche, se dirigían a Biar por motivos de unos esponsales cuando fueron asaltados por granadinos en las inmediaciones de Petrer, cayendo cautivos los dos hombres y siendo degollada la mujer. ${ }^{85} \mathrm{El}$ 1 de septiembre se reunieron en Aspe los miembros de la Hermandad con poderes para resolver este caso y para mejorar los capítulos de la misma o, incluso, para derogarla. ${ }^{86}$

Los presentes en la reunión decidieron confirmar los capítulos y acordaron que las aljamas deberían aportar 300 florines, de los cuales 200 florines serían empleados para rescatar a los dos hombres y los 100 restantes para indemnizar a los herederos de la mujer. ${ }^{87}$ Dada la celeridad con la que se llegó al acuerdo se podría pensar que se consumaron los rescates, pero la profesora Ferrer i Mallol documenta que el rescate de Grimaldos seguía sin resolver

81 A.M.O. Actas capitulares, 10, sin foliar, 9 de mayo de 1402.

82 A.M.O. Actas capitulares, 13, sin foliar, 6 de marzo de 1404.

83 NIETO FERNÁNDEZ, A.: Orihuela en sus documentos..., pp. 191 -193.

84 Ibídem, p. 203.

85 A.M.O. Actas capitulares, 13, sin foliar, 24 de agosto de 1404.

86 NIETO FERNÁNDEZ, A.: "Hermandad entre...", p. 758.

87 Ibídem, p. 758. 
en $1408 .{ }^{88}$ Los 100 florines destinados a su rescate resultarían insuficientes para sus captores, pero desconcierta que los miembros de la Hermandad no aportaran una cantidad mayor en lugar de abandonarlo a su suerte.

\section{COLABORACIÓN ENTRE ORIOLANOS Y MURCIANOS CONTRA LOS BANDIDOS DE SUS TERRITORIOS}

Una vez lograda la firma de la Hermandad a finales de 1399, Guillem Martorell, como delegado regio del rey de Aragón, negoció con el adelantado de Murcia un pacto entre la Gobernación de Orihuela y el Adelantamiento a mitad de camino entre una hermandad y un convenio de extradición. ${ }^{89}$ En primer lugar, el acuerdo planteaba que durante las paces entre Castilla y Granada, los almogávares valencianos tuvieran prohibido atravesar Murcia para atacar los enclaves fronterizos nazaríes, para así evitar que las represalias afectasen al territorio murciano, y a cambio el rey de Castilla se comprometía a negociar con Granada para que no atacaran las tierras valencianas. Y en segundo lugar, se acordaba que los cautivos y sus captores debían ser entregados a las autoridades del territorio afectado por una incursión, contemplándose incluso una indemnización por homicidios. Además, en este pacto se contemplaba la persecución de otros delitos..$^{90}$

El pacto de 1400 no debió funcionar inicialmente, por las reclamaciones que hicieron para establecer otro pacto un año después, ${ }^{91}$ pero la voluntad, en teoría, de las autoridades municipales y regionales de la Gobernación de Orihuela y del Adelantamiento de Murcia era la de colaborar en la resolución de incidentes fronterizos. Había muchos intereses en juego y las negociaciones en ocasiones derivaban en discusiones que generaban suspicacias entre los distintos agentes intervinientes en un caso. El 7 de mayo de 1401, el almogávar Andrés de Benavent cautivó en Lorca a dos moros trajineros de Baza. Lorca se apresuró a reclamar a Orihuela la devolución de los cautivos en virtud de las paces existentes entre Castilla y Granada, así como para no sufrir una represalia granadina en su espacio. ${ }^{92}$ El citado almogávar no había llevado a sus presas hasta allí, sino a Alcoy, según se supo por las averiguaciones que se estaban llevando a cabo, pero Orihuela se prestó a mediar para que le fueran devueltos los cautivos.

88 FERRER I MALLOL, M ${ }^{a}$ T.: La frontera amb l'Islam..., p. 218.

89 Ibídem, p. 206.

90 Véase VEAS ARTESEROS, F. de Asís: "Notas para el estudio de la extradición en la Edad Media", Murgetana, 82 (1990), pp. 45-72.

91 FERRER I MALLOL, $\mathrm{M}^{a}$ T.: La frontera amb l'Islam..., pp. 207-208.

92 A.M.O. Actas capitulares, 11, ff. 113r-113v. 
Sin embargo, el proceso se complicó por la supuesta actuación interesada del alfaqueque de Orihuela, Pascual del Payre. Según las autoridades lorquinas, Pascual del Payre había llegado a Lorca con la intención de ir a Granada con el objeto de rescatar a los moros presos en Alcoy por 300 doblas, pero al ser preguntado por sus fines dijo "todo lo contrario de la verdat", siendo descubiertas sus intenciones por una carta "morisca" que portaba. Lorca alegaba que bajo ningún concepto debía pagarse por esos moros, sino que tenían que ser embargados allá donde estuvieran y ser devueltos. El alfaqueque se defendió, en una carta enviada a Alcoy y leída también en Orihuela, alegando que había recibido una carta en Lorca a través de un tal Busaldo, vecino de Orihuela, en la que se recogía la posibilidad de rescatar a los cautivos por ese precio. Prosigue contando que por dicha carta fue mal recibido en Lorca, ya que los moros habían sido tomados de forma ilegal según los lorquinos, por lo que aceptaba que dichos moros fueran embargados por el mensajero que Lorca iba a enviar a Alcoy. ${ }^{93}$ Orihuela, por su parte, decidió interrogar al alfaqueque y a Busaldo por si hubieran cometido alguna irregularidad, ${ }^{94}$ pero en el caso del primero salió airoso por el apoyo que el Gobernador le brindó para que sus funciones como alfaqueque no fueran cuestionadas. ${ }^{95}$

En otras ocasiones, la protección que los señores daban a sus vasallos implicados en robos y secuestros dificultaba la entrega de bandidos y cautivos en incidentes producidos entre las tierras de la Gobernación y del Adelantamiento. Sucedió así en varios incidentes protagonizados por moros del valle del Ricote, vasallos de la Orden de Santiago, ${ }^{96}$ a inicios del cuatrocientos. En el primero de ellos, en julio de 1401, dos hombres a caballo y un ballestero, entre ellos el famoso renegado conocido como el Chinchillano, entraron por la huerta de Orihuela hacia la Punta de Cegua e hirieron a un hombre. El lugarteniente del Gobernador les siguió hasta la encomienda de Ricote y le exigió a su alcaide la entrega de los bandidos, pero éste se negó.

Y en febrero de 1402, moros de Blanca y Ulea saltearon en el puerto de Crevillente a cuatro hombres que venían a Orihuela para avecindarse junto a sus mujeres e hijos. En el asalto degollaron a un niño, ataron a las mujeres a unos árboles y se llevaron al resto hasta Blanca. De nuevo los hombres que salieron al apellido desde Elche, Nompot, Crevillente y Callosa no pudieron abortar la agresión, y recibieron una nueva negativa cuando llegaron a la

93 A.M.O. Actas capitulares, 11, ff. 118v-119v.

94 A.M.O. Actas capitulares, 11, ff. 119v-120v.

95 A.M.O. Actas capitulares, 11, f. 130v.

96 VEAS ARTESEROS, F. de Asís: "El sureste...", p. 45. 
encomienda y solicitaron la entrega de los cautivos. ${ }^{97}$ En este caso intervino el lugarteniente del adelantado a favor de Orihuela, ya que escribió una carta al comendador de Ricote, y mostró su predisposición a elevar la causa al rey de Castilla y al maestre de la Orden de Santiago, pero su intercesión no causó efecto porque el comendador exculpó a sus vasallos. ${ }^{98}$

El siguiente caso se logró resolver, cierto es que no hubo que lidiar con jurisdicción señorial alguna. El 21 de junio de 1402 fueron salteados en las inmediaciones del Cap de Cerver dos moros que fueron llevados hasta Cartagena. Según la hermandad vigente, las universidades de cristianos debían proceder a su búsqueda y liberación, misión que emprendieron de inmediato. En este caso no se habría llegado a pagar rescate, pues los moros fueron liberados por la intervención del adelantado de Murcia y el merino de Cartagena. ${ }^{99}$

Entre 1403 y 1404, la comunicación entre Orihuela y Murcia se alteró por las numerosas incidencias que se estaban produciendo a un lado y otro de la frontera, hecho que ralentizó la resolución de los incidentes. Uno de los principales escollos que encontraron las autoridades fue la identificación y localización de los delincuentes. A finales de 1403 Murcia presentó una queja a Orihuela por no haber detenido a los sospechosos del cautiverio en Orihuela de dos moros de Murcia, Gali Taher y Giim Ricot, a inicios de 1402. En ese momento las autoridades oriolanas interrogaron al exea oriolano, Jacme Carbonell, y a Pascual Robiols, vecino de Murcia que medió en la liberación, quienes declararon que el rescate se produjo a cambio de 100 florines y que entre los implicados había cuatro hombres de Murcia y dos de Orihuela, por lo que se trataría de una banda plurinacional. ${ }^{100}$ Tras la declaración buscaron a los supuestos oriolanos mencionados, pero como no fueron encontrados abandonaron el caso. Murcia, además de la detención de los implicados, reclamaba que éstos devolvieran el rescate. ${ }^{101}$

Orihuela respondió que los moros perjudicados no habían presentado denuncia, pero desde Murcia sostenían lo contrario, y ante la dilatación del proceso tomó partida en él el adelantado de Murcia. Los datos aportados sobre los malhechores, además, seguían causando dudas, pues las autoridades murcianas decían conocer que éstos tenían sus casas y sus mujeres en Orihuela, y las autoridades oriolanas propusieron que esos 100 florines fueran

97 NIETO FERNÁNDEZ, A.: Orihuela en sus documentos..., pp. 161-162; Pedro BELLOT, op. cit., p. 192.

98 NIETO FERNÁNDEZ, A.: Orihuela en sus documentos..., p. 164.

99 Ibídem, pp. 180, 181 y 186.

100 CABEZUELO PLIEGO, J. V.: "Guerra y violencia...", p. 53.

101 A.M.O. Actas capitulares, 13, sin foliar, 3 de diciembre de 1403. 
cobrados de los supuestos murcianos y oriolanos implicados en proporción. El tono de las cartas comenzaba a ser altivo debido a la falta de entendimiento, y las amenazas de una represalia para cobrarse los 100 florines comenzaban a cobrar fuerza. ${ }^{102}$ Orihuela pidió a Murcia que no tomara represalia, pero enredó todavía más el asunto cuando reclamó la detención de los malhechores que tomaron a dos moros de Albatera, acusando al adelantado de tener detenidos a espías y tratadores implicados en dicho asalto, ${ }^{103}$ así como la devolución de los gastos derivados de su rescate. ${ }^{104}$

La discusión se alargaba sin aparente solución, pero la comunicación entre Murcia y Orihuela se relajó y ambas expresaron su predisposición a perseguir a los malhechores. De hecho, desde Murcia llegaron noticias de un hombre arrestado por su participación en el asalto de los moros de Albatera. ${ }^{105}$

\section{CONCLUSIONES}

La recopilación y comparación de noticias referidas a incidentes fronterizos acaecidos en el marco de instituciones arbitradoras o pactos para resolver incidentes violentos, confirman los problemas que tuvieron para resultar eficaces tanto la hermandad entre cristianos y musulmanes en la Gobernación de Orihuela como los pactos o las conversaciones entre Orihuela y Murcia.

Los agentes diplomáticos, como los mensajeros y los alfaqueques o exeas, tuvieron amplias competencias diplomáticas entre consells, concejos y aljamas, siendo responsables del fomento de relaciones interregionales cordiales y del rescate de cautivos. ${ }^{106}$ Estos agentes debían ser muy hábiles en su labor y saber manejar varios canales de comunicación en paralelo. Y se puede decir que su misión no fue en balde si atendemos a que en la frontera del sudeste peninsular las estrechas relaciones sociales y económicas no sucumbieron a la intranquilidad o inestabilidad imperante. Las autoridades locales y regionales rayanas, a través de estos agentes, supieron hacer prevalecer la paz sobre la conflictividad o la guerra en la frontera mediante el control de los niveles de violencia. ${ }^{107}$ El fenómeno de la violencia formaba parte del carácter

102 A.M.O. Actas capitulares, 13, sin foliar, 16 de enero de 1404.

103 CABEZUELO PLIEGO, J. V.: "El negocio del rapto...", p. 55.

104 A.M.O., Actas capitulares, 13, sin foliar, 22 de enero de 1404 Estos dos moros fueron rescatados en el marco de la hermandad, véase nota 84.

105 NIETO FERNÁNDEZ, A.: Orihuela en sus documentos..., pp. 205-206.

106 JIMÉNEZ ALCÁZAR, J. F.: "Relaciones interterritoriales...", p. 579.

107 LÓPEZ GARCÍA, J. C.: art. cit., p. 22. 
de la frontera, era inherente al espacio, por lo que la paz nunca se llegó a consolidar. La frontera, por lo tanto, se mantuvo en un estado prebélico permanente en el que a través de la diplomacia y las acciones armadas se regulaban las relaciones de las tres soberanías presentes en el sudeste peninsular. ${ }^{108}$

Mediante el control de los niveles de violencia se trató de atajar los problemas derivados de acciones al margen de la ley de individuos que hicieron de la violencia su medio de vida. En el caso de la Hermandad, estudios previos sobre esta institución han considerado que funcionó porque las comunidades se negarían a permitir unos incidentes por los cuales tendrían que pagar y porque se sentirían más seguros al disminuir la eficacia de las acciones violentas. ${ }^{109}$

Esos podrían ser los efectos inmediatos, pero la realidad es que durante los años de la Hermandad las tierras de la Gobernación fueron continuamente golpeadas, con más o menos virulencia, por castellanos, mudéjares murcianos, granadinos y renegados. ${ }^{110} \mathrm{Si}$ acaso logró poner freno al quintacolumnismo de los mudéjares valencianos. En cambio, parece haber una tendencia a una menor actividad violenta entre 1405 y 1407, es decir, durante los primeros años del tratado de paz entre la Corona de Aragón y el Reino de Granada. Para los años del interregno no tenemos apenas referencias, pero la tendencia de los niveles de violencia a partir de 1412 sigue siendo alta y da síntomas de un repunte del quintacolumnismo mudéjar. ${ }^{111}$

La Hermandad murió con Martín I, su principal valedor junto a las aljamas musulmanas. Éstas podrían haber sentido relativamente una mayor seguridad durante la Hermandad porque la comunidad cristiana se mostró más ágil a la hora de restituir a las víctimas mudéjares. Las villas cristianas, con Orihuela a la cabeza, percibirían la Hermandad como algo impuesto ${ }^{112}$ por las presiones recibidas por el comisario regio y porque tuvieron que hacer frente a numerosas multas y rescates por las frecuentes incursiones castellanas. El sector villenense perdería fuelle, pero desde el sur los asaltos contra los mudéjares de la Gobernación no cesaron.

Las propuestas que realizaron las villas cristianas para modificar la Hermandad en 1401 podrían responder a varios objetivos. En primer lugar,

108 Ibídem, art. cit., p. 21.

109 TORRES FONTES, J.: "La hermandad de moros y cristianos...", p. 506; NIETO FERNÁNDEZ, A. "La Hermandad entre...", p. 759.

110 Véase la tabla anexa.

111 A.M.E. Libro de ordenaciones del Consell, 3, ff. 149v-152r.

112 NIETO FERNÁNDEZ, A.: Orihuela en sus documentos..., p. 137. Sin embargo, el propio Nieto Fernández ve en su renovación cada dos años signos de eficacia y de voluntariedad para firmar o romper el pacto ("La Hermandad entre...", p. 759). 
ahogar a las comunidades mudéjares de señorío del valle de Elda con la duplicación de la cuantía correspondiente a la multa por víctima cristiana. Y en segundo lugar, con la propuesta de no entregar toda la indemnización a los herederos, sino repartirla entre éstos y su universidad o aljama de origen, buscarían obtener un beneficio económico extraordinario por formar parte de la Hermandad. Ahora bien, no tenían nada que perder, por eso tensaron tanto la cuerda ante unas aljamas que no estaban dispuestas a perder la protección de la Hermandad. En cuanto a los pactos entre Orihuela y Murcia se puede decir que no ayudó a complementar a la Hermandad. Ambos sistemas de control de la violencia se mostraron en ocasiones desbordados por las circunstancias y dieron sensación de enredarse en una pesada madeja jurisdiccional y burocrática que generaba conflictos jurisdiccionales, pleitos $\mathrm{y}$ tensas relaciones interregionales.

En conclusión, las comunidades implicadas en este tipo de acuerdos se relacionaron en los mismos a través de un sistema de interacción que implicaba, en primer lugar, negociaciones para el rescate de cautivos y la entrega de bandidos; en segundo lugar, confrontación por los intereses opuestos de las partes implicadas; y en tercer lugar connivencia con los delincuentes a causa de esa confrontación y de la puntual falta de celo en la persecución y entrega de bandidos. 


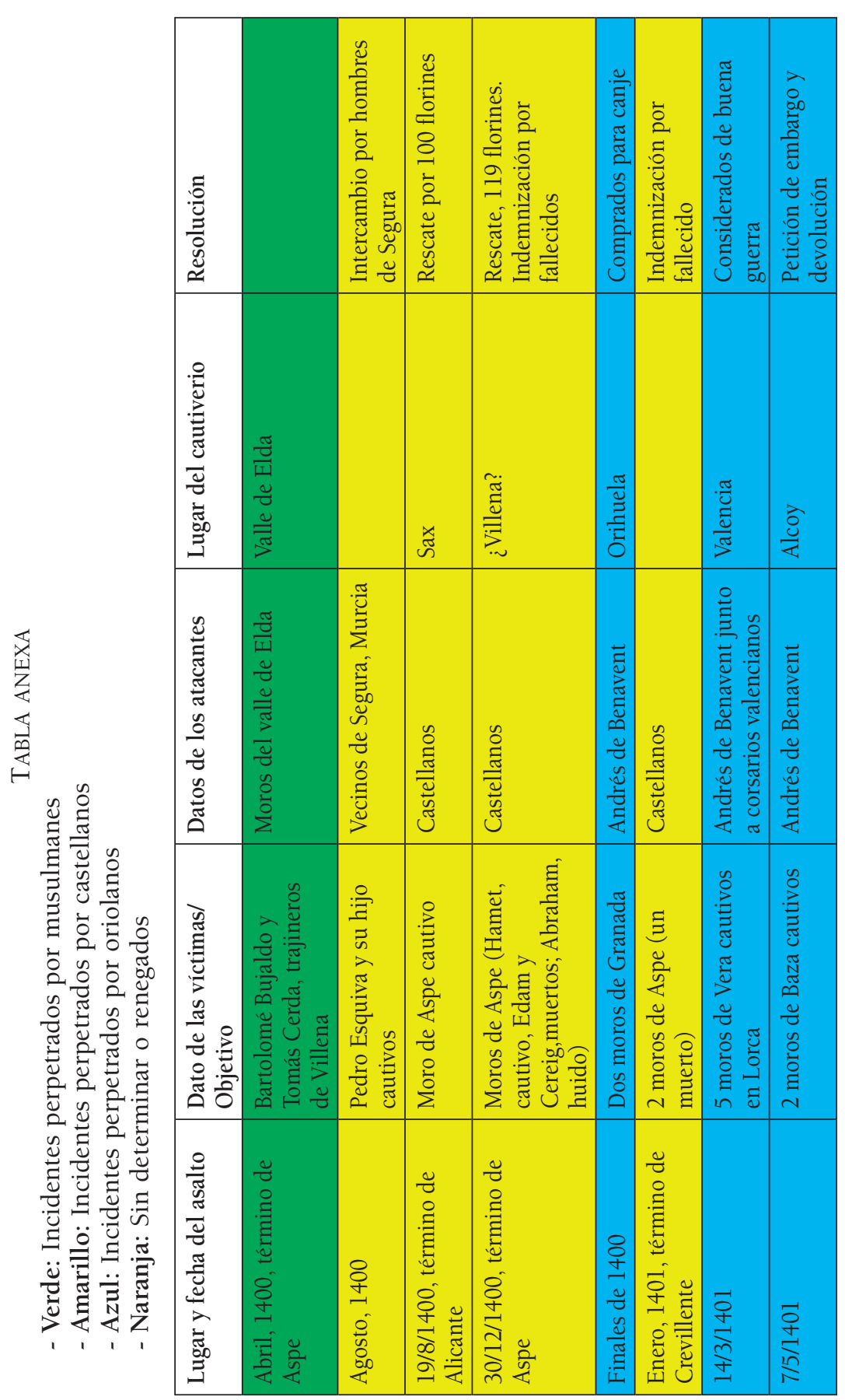




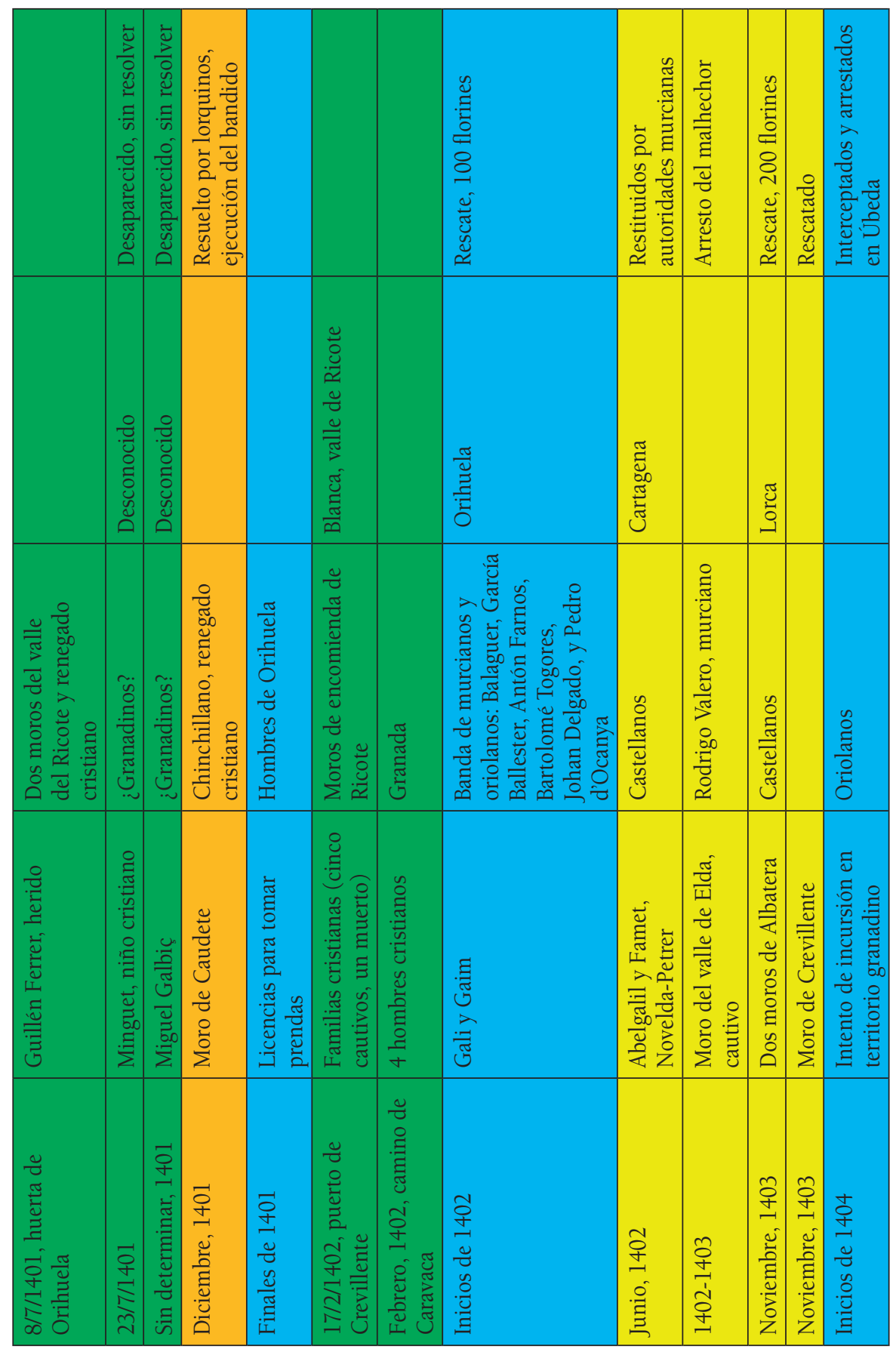


Pactos y tensiones en un espacio de pluralidad identitaria y jurisdiccional...

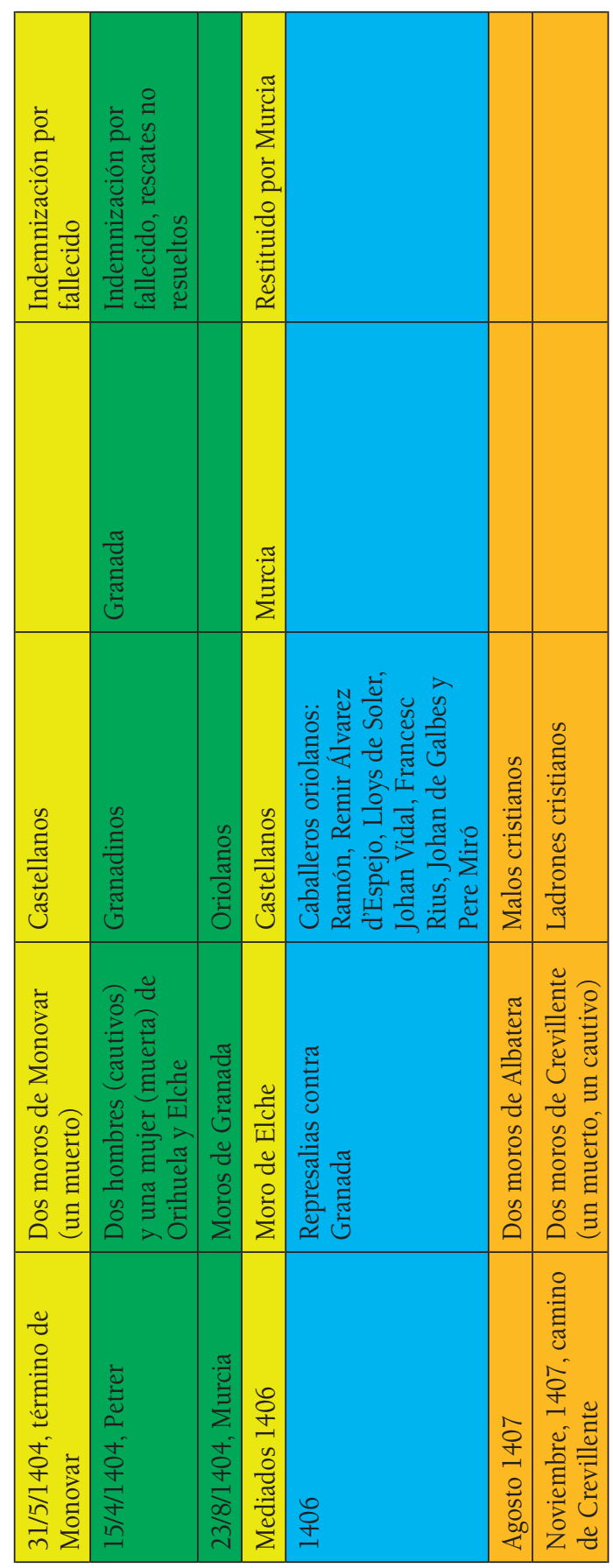




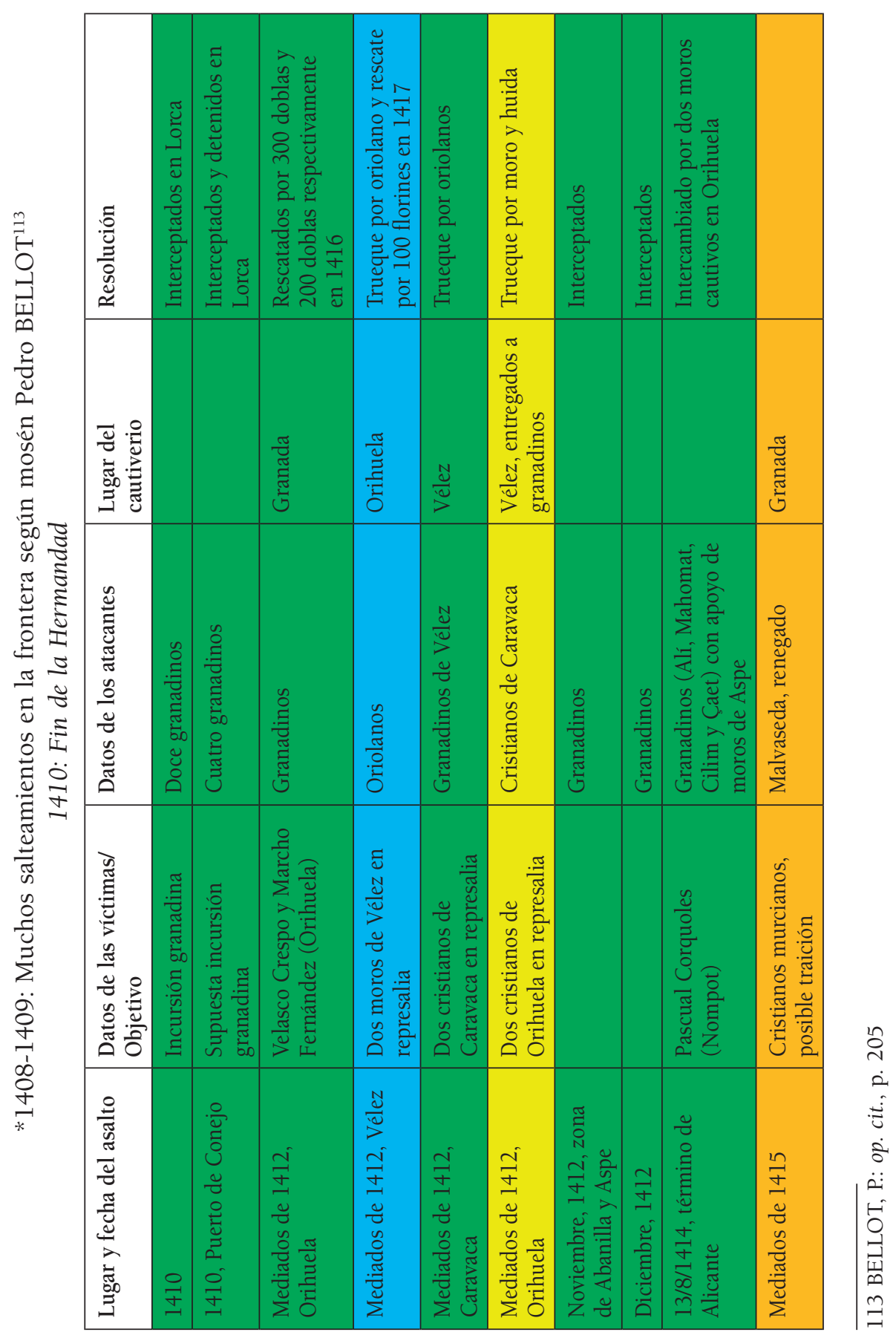

